\title{
Den Europæiske Union: Supranationalt demokrati eller international konsolideringsstat?
}

Malte Frøslee Ibsen

Akademiske debatter tiltrækker sjældent offentlighedens opmærksomhed. I de få tilfælde, de gør, er de oftest præget af polemik, intriger og personangreb snarere end indhold af substantiel offentlig relevans. En markant undtagelse fra denne regel er dog debatten mellem filosoffen Jürgen Habermas og den politiske økonom Wolfgang Streeck, der i 2013 var genstand for bred interesse i den lærde tyske offentlighed. Disputten mellem Habermas og Streeck udmærker sig ved at være renset for den polemiske og aggressive form, som for eksempel prægede de offentlige sværdslag mellem filosofferne Axel Honneth og Peter Sloterdijk i 2009. Hvad vigtigere er, så er debattens substantielle problemstillinger af ubestridelig offentlig interesse: nemlig, forholdet mellem demokrati og kapitalisme i Europa, EU's fremtid, samt hvordan den europæiske venstrefløj skal stille sig overfor én af grundstenene i det realiserede europæiske projekt: Den Økonomiske og Monetære Union.

Den store offentlige interesse skyldes naturligvis også, at debattens kontrahenter ikke er hvem som helst. Jürgen Habermas er den måske mest indflydelsesrige nulevende filosof i verden samt én af den tyske forbundsrepubliks mest prominente offentlige intellektuelle. Hans tidligste arbejde var stærkt præget af den såkaldte Frankfurterskole, som Habermas sammen med Max Horkheimer, Theodor W. Adorno, og Herbert Marcuse ofte regnes med til, og hans filosofiske og sociologiske værk har været orienteret mod at udvikle en kritisk samfundsteori med udgangspunkt i grundbegrebet 'kommunikativ handlen' samt en 'diskursteori om den moderne demokratiske retsstat. I sit seneste arbejde har Habermas udfoldet en hypotese om, at globaliseringen undergraver de eksisterende betingelser for demokratisk selvbestemmelse, samt et normativt forslag om at 
forfølge en kosmopolitisk forfatning for verdenssamfundet i Immanuel Kants ånd. Det er præcis i denne kontekst, vi også finder det projekt, som Habermas gennem de senere år er blevet måske mest kendt for i offentligheden: nemlig, et kompromisløst forsvar for og en gentænkning af EU som et supranationalt demokrati.

Wolfgang Streeck er en generation yngre end Habermas, men hans arbejde har ligesom Habermas' rødder i den tyske tradition for kritisk samfundsteori. Streeck har dog forfulgt et mere konsekvent fokus på politisk økonomi end tænkerne omkring Frankfurterskolen, der orienterede sig mere mod filosofi, kulturkritik, og sociologi. Streeck har i de senere år især gjort sig bemærket med sin kritik af den såkaldte Austeritätspolitik, samt ikke mindst de Adorno-Forelæsninger, han afholdt i Frankfurt i 2012, og som senere blev til hans meget omdiskuterede bog Gekaufte Zeit (2013). ${ }^{14}$ Bogen præsenterer Streecks forklaring på den kombinerede bankkrise, finanskrise, og realøkonomiske krise fra 2008 - en forklaring som bl.a. den britiske avis The Financial Times har kaldt "the most powerful description of what has gone wrong in western societies". ${ }^{15}$ Det er da også med udgangspunkt i denne forklaring, at Streecks mange offentlige interventioner siden finanskrisen - og, ikke mindst, debatten med Habermas - har taget deres udgangspunkt.

I denne artikel vil jeg skitsere debatten mellem Habermas og Streeck som afsæt for en diskussion af EU's fremtid: Er (eller bør) den Europæiske Union (være) på vej mod et supranationalt demokrati, som Habermas plæderer for, eller tager EU snarere ufravigeligt form af en international 'konsolideringsstat', der ikke indenfor nogen realistiske horisonter kan demokratiseres, som Streeck fastholder? Som vi skal se, så er begrebet 'supranationalt demokrati' ikke lig en føderal stat i Habermas' optik, men han insisterer på, at den økonomiske politik i Eurozonen må koordineres fra Bruxelles med udgangspunkt $i$ et styrket Europæisk Parlament, hvis 'politikken' skal gøre sig noget håb om at genvinde kontrol med 'markedet' på det europæiske kontinent. Heroverfor står Streecks kompromisløse fastholden af, at EU i dag er en utvetydigt antidemokratisk kraft, der bidrager til at reducere medlemsstaterne til en slags politiske gældsslaver, og som ophæver den neoliberale sparedoktrin til et supranationalt diktat uden for demokratiske

\footnotetext{
${ }^{14}$ I det følgende vil jeg inkludere referencer til de oprindelige tyske udgivelser men citere fra de engelske oversættelser, når dette er muligt.

15 Financial Times, "The protests failed but capitalism is still in the dock", http://www.ft.com/cms/s/0/1a505772-1114-11e1-a95c-00144feabdc0.html\#axzz41b3X9ZNW (accessed 29 February, 2016)
} 
flertals og folkevalgte politikeres rækkevidde. I det første afsnit vil jeg indledningsvist skitsere argumentet i Streecks Gekaufte Zeit og de centrale kritikpunkter i Habermas' anmeldelse af bogen. I det andet afsnit dykker jeg dybere ned i det teoretiske udgangspunkt for Habermas' kritik og skitserer grundelementerne i hans social- og demokratiteori. I tredje og sidste afsnit redegør jeg for Streecks svar til Habermas og diskuterer styrkerne og svaghederne ved deres respektive argumenter.

Debatten mellem Habermas og Streeck udspillede sig i det lille, men velansete tyske tidsskrift Blätter für deutsche und internationale Politik, og den har siden dannet grundlag for antologien Demokratie oder Kapitalismus? Europa in der Krise, der også samler op på de mange tilstødende debatter, der fulgte i dens kølvand. Det første træk i debatten var Habermas' anmeldelse af Gekaufte Zeit - en bog hvis analytiske originalitet og politiske sprængkraft Habermas sammenligner med Karl Marx’ historiske mesterværk, Der achtzehnte Brumaire des Louis Bonaparte (Habermas 2013). Habermas' store begejstring for Streecks analyse har da også en ganske naturlig forklaring, idet den teoretiske ramme, som Streeck udfolder sin analyse af krisens årsager på baggrund af, er en begrebslig opdatering af den såkaldte legitimationskriseteori, som Habermas og Claus Offe udviklede i de tidligere 1970ere (Habermas 1973; Offe 2006).

Habermas' og Offes teori tog udgangspunkt i en hypotese om, at efterkrigstidens 'senkapitalistiske' samfund gennem planlægning og statsregulering havde overvundet den laissez-faire-kapitalistiske økonomis cykliske krisedisposition og formidlet et klassekompromis mellem kapital og arbejdskraft. Dette havde dog den utilsigtede konsekvens, at den kapitalistiske økonomis indbyggede modsætningsforhold blev overført til forholdet mellem 'det politiske system' og 'det sociokulturelle system'. Herved, lød tesen, var tidligere tiders økonomiske kriser blevet afløst af 'legitimationskriser', hvor konsekvensen ikke er et sammenbrud i produktionen, men snarere at store dele af befolkningen trækker støtten til den sociale orden. For Streeck repræsenterer dette entydige skift i fokus fra klassekampen og den kapitalistiske økonomis 'styrbarhed' til et kapitalistisk samfunds sociale og kulturelle legitimation, en fatal teoretisk fejltagelse: 
What appeared critical to them [Habermas \& Offe] was not the technical governability of modern capitalism but its social and cultural legitimation. Underestimating capital as a political actor and a strategic social force, while at the same time overestimating the capacity of government policy to plan and to act, they thus replaced economic theory with theories of the state and democracy; the penalty they paid was to forgo a key part of Marx's legacy. (Streeck 2014a, 32).

Af samme grund måtte legitimationskriseteorien ifølge Streeck nødvendigvis være blind for den strukturelle forandring i de kapitalistiske økonomier, som tog sin begyndelse i netop 1970erne, og som havde som primærkonsekvens, at de stadigt mere globaliserede markeder i stigende grad frigjorde sig fra de begrænsninger, som den demokratiske politik havde pålagt den private profitskabelse.

Streecks løsning på dette problem er at udvide Habermas’og Offes legitimationskriseteori med en ekstra akse, således at et demokratisk-kapitalistisk samfunds overlevelsesdygtighed ses som værende afhængig af statens kapacitet til at opfylde to gensidigt uafhængige legitimationsbehov: dels dens borgeres forventning om velstand og social retfærdighed, dels kapitalejernes forventning om et højt og stabilt afkast på deres investeringer. En af Streeks teoretiske innovationer i Gekaufte Zeit er således at opfatte såvel demokratiske fællesskaber eller lønmodtagere (to kategorier han har tendens til at ækvivalere) såvel som kapitalen - eller kapitalejerne - som strategiske aktører. Denne udvidelse af legitimationskriseteorien baner vejen for én af bogens hovedteser, nemlig at det var kapitalejernes (bevidst eller ubevidst) koordinerede investeringstilbageholdenhed, der var den primære årsag til afviklingen af den statsregulerede 'senkapitalisme' og dermed repræsenterede den unilaterale opsigelse af "the postwar settlement of democratic capitalism" mellem kapital og arbejdskraft (Streeck 2014a, 62).

Med andre ord, så skal roden til nutidens kombinerede bankkrise, gældskrise, og realøkonomiske krise findes i den 'investeringsstrejke', som kapitalejerne indledte i 1970erne, motiveret af utilfredshed med profitniveauet under den keynesianske spændetrøje, som de var blevet pålagt af efterkrigstidens interventionistiske velfærdsstat. Denne investeringsstrejke havde til direkte formål at skabe mere gunstige vilkår for kapitalakkumulation, og med den gradvise teknologiske og geopolitiske muliggørelse af kapitalens globale mobilitet befandt kapitalejerne sig endelig i en situation, hvor de kunne frigøre en stadigt større del af afkastet til dem selv. Denne tendens har eksempelvis haft 
som resultat, at væksten i reallønnen for det store flertal af amerikanske lønmodtagere er stagneret siden slutningen af 1970erne, trods perioder med betragtelig økonomisk vækst (Mischel et al 2011).

I takt med globaliseringen har den stigende internationale skattekonkurrence og kapitalejeres og virksomheders nye muligheder for systematisk skatteunddragelse haft dramatiske konsekvenser for de demokratiske velfærdsstaters muligheder for at finansiere det offentlige forbrug. Ifølge Streeck var velfærdsstaternes svar på denne legitimations-/finansieringskrise på kapitalaksen at forsøge at erstatte den mistede skattefinansiering gennem række penge- og finanspolitiske eksperimenter: først gennem inflation af pengemængden (1970erne og 80erne), der kun kunne bringes under kontrol med skyhøje renter og knægtelsen af lønmodtagerorganisationer; dernæst gennem offentlig gæld (80erne og 90erne) i en periode med høj arbejdsløshed; hvilket endelig blev efterfulgt af konsolideringen af de offentlige budgetter og den deregulering af de private kreditmarkeder og resulterende 'finansialisering' af kapitalismen (90erne og 00erne), der kulminerede i bank- og finanskrisen i 2008 og den efterfølgende 'Great Recession' i realøkonomien. Således lykkedes det de demokratiske velfærdsstater at 'købe tid' (deraf bogens titel) gennem en række penge- og finanspolitiske fiksfakserier, der dog i hvert tilfælde kun holdt så længe, de ikke kom i karambolage med kapitalens - og, i særdelshed, den stadigt mere magtfulde finanskapitals - krav om et stabilt højt afkast.

I dag er pengemagien dog tilsyneladende sluppet op. Efter den enorme private kreditboble sprang og de globale finansmarkeder kollapsede i et historisk firesale i 2008, har staterne været tvunget til at nationalisere store dele af den dårlige private gæld enten gennem regeringers bail-outs af private banker eller ved centralbankernes massive opkøb af private og offentlige finansielle tilgodehavender, den såkaldte quantitative easing. Distinktionen mellem privat og offentlig gæld er dog reelt brudt sammen efter 2008, ikke mindst fordi staternes kreditværdighed i ligeså høj grad som størrelsen på deres gæld og strukturelle underskud er afhængig af deres finansielle frirum til at kunne fungere som virtuel garant for store private banker - et hensyn, der har fungeret som central drivkraft i den austerity-politik, som er blevet forfulgt over hele Europa (Blyth 2013). Ifølge Streeck befinder de kapitalistiske demokratier sig nu i en situation, hvor den offentlige gæld som resultat af bankkrisen, finanskrisen og den realøkonomiske krise igen er eksploderet, og hvor de tilmed står overfor en samlet privat gæld, der er 
endnu større end før bankkrisen i 2008 (Dobbs et al 2015). Deres muligheder for at finansiere det offentlige forbrug gennem pengemagi synes altså opbrugt, og de er godt på vej mod at blive reducerede til statslige gældsslaver for stadigt mere velhavende finanskapitalejere, alt imens velfærden beskæres for at bevare deres 'kreditværdighed' på finansmarkederne og hos rating-bureauerne.

Streecks påstand er, at denne udvikling har forårsaget en grundlæggende forandring i staternes karakter: efterkrigstidens 'skattestater' (der finansierede deres forbrug gennem skatteinddrivning) blev i takt med globaliseringen gradvist erstattet af 'gældsstater' (der finansierede deres forbrug gennem optagningen af kredit på de private finansmarkeder), der i dag er ved at blive omdannet til, hvad Streeck kalder den neoliberale 'konsolideringsstat' - altså stater med et indirekte ansvar for et ustabilt privat kreditmarked og et permanent højt underskud på de offentlige budgetter, der må konsolideres uendeligt gennem udgiftsbesparelser (og 'incitamentsskabende' skattelettelser, der igen provokerer yderligere besparelser) for at bevare deres kreditværdighed. Ifølge Streeck er denne strukturelle forandringsproces ydermere gået hånd $\mathrm{i}$ hånd med en forskydning mellem de respektive constituencies, som den demokratiske velfærdsstat tjener.

I overensstemmelse med de to akser i Streecks legitimationskriseteori identificerer han to legitimationsprincipper for den demokratiske velfærdsstat: markedsretfcerdighed, der refererer til fordelingen af "the output of production according to the market evaluation of individual performance", og social retfaerdighed, der refererer til kulturelle normer om menneskerettigheder og "collective ideas of fairness, correctness and reciprocity" (Streeck 2014a, 132-133). Disse to principper svarer til to forskellige "constituencies": hvad Streeck kalder markedsfolket (kapitalejerne) og statsfolket (borgerne). I den neoliberale konsolideringsstat har finanskapitalen reelt opnået så fast et greb om den demokratiske politik, at den har indsat sig selv som det dominerende "second constituency" på bekostning af statsfolket og den demokratiske selvbestemmelse (Streeck 2014a, 162). Det er vigtigt at understrege, at denne "de-democratization of capitalism" ikke er foregået ved et formelt og åbenlyst coup d'état, men snarere gennem "the deeconomization of democracy" - altså en de facto udhuling af statens de jure økonomiske suverænitet. Dette er baggrunden for Streecks ekstremt pessimistiske vurdering af demokratiets fremtid: "the clock is ticking for democracy as we have come to know it, as 
it is about to be sterilized as redistributive mass democracy and reduced to a combination of the rule of law and public entertainment." (Streeck 2014a, 36)

Det er i denne kontekst, at EU ifølge Streeck spiller en nøglerolle. Efter gælds- og konsolideringsstatens opståen har EU nemlig tjent den entydige funktion at ophæve og fastholde finansmarkedets konsolideringskrav til et supranationalt niveau, uden for de folkevalgte nationale parlamenters indflydelsessfære. Streeck refererer derfor til EU som en 'international konsolideringsstat', hvor krav om maksimumværdier for offentlig gæld og det strukturelle underskud er skrevet ind i den fælles europæiske forfatning, der begynder at tage form ('Finanspagten'; i Danmark frivilligt vedtaget som 'budgetloven'). Den Økonomiske og Monetære Union (ØMU'en) spiller en nøglerolle i dette forsøg på en gennemgribende afdemokratisering af den europæiske kapitalisme, da den fratager medlemslandene i Eurozonen muligheden for udligne forskelle i konkurrenceevne og løse interne fordelingskonflikter gennem devaluering af deres valuta. I stedet tillader ØMU'en udelukkende økonomisker redskaber for forbedringer af konkurrenceevnen (påkrævet af konsolideringsforfatningen) med karakter af såkaldt 'intern devaluering', altså hårde offentlige udgiftsbesparelser, 'fleksibilisering' af arbejdsmarkedet gennem løndumping og opløsning af lønmodtagerorganisering, privatisering af offentlig service, osv. Streeck drager på denne baggrund en drastisk konklusion: ØMU'en må opsiges og erstattes af et 'europæisk Bretton Woods', og vi må besinde os på en tilbagevenden til nationalstaten som omdrejningspunktet for modstand mod "markettechnocratic eurofanaticism and the final institutional triumph of the consolidation state" (Streeck 2014a, 365).

I sin anmeldelse af Gekaufte Zeit erklærer Habermas sig i det store hele enig i Streecks analyse. Det gælder for såvel udvidelsen af legitimationskriseteorien med kapitalaksen som for analysen af velfærdsstaternes forsøg på at købe tid, kulminerende i den neoliberale konsolideringsstat. Habermas deler altså til fulde Streecks opfattelse af og bekymring over afdemokratiseringen af den europæiske kapitalisme, og de deler ligeledes intentionen om at identificere en farbar praktisk vej, hvorved 'politikken' og den demokratiske selvbestemmelse kan genvinde overhøjheden over 'markedet' og undslippe finansmarkedernes kvælertag om de offentlige finanser. Denne konsekvente enighed om baggrundsanalysen gør kun deres dybe og systematiske uenighed om de respektive veje til dette fælles mål, som de hver især identificerer, desto mere påfaldende: ifølge 
Habermas vælger Streeck på overraskende vis den 'nostalgiske' vej "of retreating into the sovereign impotence of the overrun nation", mens Frankfurterfilosoffen kompromisløst advokerer for en udvidelse af Unionen til et "supranationalt demokrati" (Habermas $2015,89)$.

Før vi udforsker denne praktiske uenighed lidt nærmere, er det dog vigtigt at have i betragtning, at Habermas' kritik af Streeck ikke er uden basis i sidstnævntes egen analyse. Habermas identificerer en række systematiske overvejelser i Gekaufte Zeit, der peger i retning af, at en tilbagetrækning til nationalstaten vil have mere end svært ved at opfylde de normative forhåbninger, som Streeck og Habermas deler:

\begin{abstract}
Wolfgang Streeck is of course aware that 'the power of investors feeds mainly on their advanced international integration and the presence of efficient global capital markets'. Looking back on the global victory march of deregulation policy, he emphasizes that he has to 'leave it open whether and how, in an increasingly international economy, nationally organized democratic politics could have successfully brought such developments under control'. He repeatedly emphasizes the 'organizational advantage that globally integrated financial markets have over nationally organized societies'. Hence, one might think that his own analysis would force him to conclude that the power of democratic legislation to regulate markets, which was at one time concentrated in the nation-states, should be restored at the supranational level. In spite of this, he sounds the retreat behind the Maginot Line of national sovereignty. (Habermas
\end{abstract} 2015, 90-91)

Ifølge Habermas anbefaler Streeck altså en tilbagetrækning til en nationalstatslig ramme, som han selv giver overbevisende grunde til at tro ikke vil vaere $i$ stand at undslippe de globale markeders og den globale finanskapitals skruetvinge om demokratiernes udhulede økonomiske suvercenitet. Omvendt er det præcis, hvad Habermas kalder "the political fragmentation of a nevertheless economically integrated world society" (Habermas 2015, 90), som motiverer hans konsekvente insisteren på, at den rigtige vej at gå ikke er tilbage til nationalstaten, men snarere frem mod en nytænkning af EU som et supranationalt demokrati. For at forstå Habermas’ principielle forsvar for det europæiske projekt bliver vi dog nødt til først at tage et lidt mere synoptisk blik på hans filosofiske og sociologiske virke. 
Habermas' teoretiske livsværk har været drevet af en intention om at udvikle en kritisk teori om det moderne kapitalistiske samfund - det vil sige en samfundsteori, der belyser systematiske kilder til ufrihed og identificerer praktiske muligheder for at imødegå dem. Til dette formål har Habermas udviklet et komplekst og omfattende social- og demokratiteoretisk begrebsapparat, der især udfoldes i de to hovedværker Theorie des Koтmunikativen Handels og Faktizität und Geltung. Hans socialteori udgør et forsøg på udvikle en generel teoretisk ramme for at forstå det moderne samfunds reproduktionsbetingelser og drivkraften i menneskets sociale udviklingshistorie. I lyset af omfanget af Habermas' produktion må den følgende, introducerende oversigt nødvendigvis forblive yderst kursorisk.

Den centrale skelnen i Habermas' socialteori er en (klassisk) distinktion mellem to former for samfundsmæssig integration, der forløber gennem to forskellige former for handlingskoordinering: på den ene side den sociale integration, der forløber gennem kommunikativ handlen (handlen orienteret mod fælles forståelse), og på den anden side funktionel integration, der forløber gennem strategisk handlen (handlen orienteret mod succes) (Habermas 1981a, 384-385). Denne dualistiske begrebsstruktur giver sig udslag i et todelt metodisk blik på det moderne samfund som på én og samme tid en livsverden (socialt integreret gennem kommunikativ handlen) og et system af systemer (funktionelt integreret gennem strategisk handlen). Mere specifikt argumenterer Habermas for, at handlen orienteret mod fælles forståelse i sidste instans foregår gennem udvekslingen af argumenter og fornuftsgrunde (uanset om de er indforståede eller ekspliciterede), og at den kommunikative handlen dermed hviler på en række krævende normative forudsætninger, mens den strategiske handlen begrænses til en indstilling overfor interaktionspartneren som et middel til ens egne mål. I det komplekse og funktionelt differentierede samfund er funktionelle systemer af strategisk handlen brudt ud af livsverdenen og integreres udelukkende gennem styringsmedier, såsom penge, der ligger til grund for det økonomiske subsystem, og magt, der ifølge Habermas ligger til grund for det administrative subsystem, den offentlige forvaltning.

I Habermas' demokratiteori udbygges denne dualistiske socialteori med en rekonstruktion af den demokratiske retsstats normative selvforståelse, samt en teori om muligheden for demokratisk legitimering af magten og administrativ styring af det økono- 
miske subsystem i et moderne demokratisk-kapitalistisk samfund. Som Kant forstår Habermas frihed som indbegrebet af selvbestemmelse (eller autonomi) i overensstemmelse med universelt retfærdiggjorte normer. Han reformulerer dog Kants monologiske 'kategoriske imperativ' som et dialogisk diskursprincip: "Just those action norms are valid to which all possibly affected persons could agree as participants in rational discourses" (Habermas 1996, 107). Ifølge Habermas kan den demokratiske retsstats normative grundprincip - hvad han slet og ret kalder det demokratiske princip - forstås som en begrebslig sammensmeltning af diskursprincippet og den retslige form: "Only those statutes may claim legitimacy that can meet with the assent of all citizens in a discursive process of legislation that in turn has been legally constituted". Den normative kerne i Habermas' rekonstruktion af den demokratiske retsstats normative grundlag er altså en kantiansk kobling mellem demokratisk selvbestemmelse og gensidig retfærdiggørelse af love mellem borgere, hvor den form for frihed, man som borger nyder i et demokratisk fællesskab, forstås som efterlevelse af love, der ideelt set kan accepteres af alle medborgere i samfundet.

Når man kobler Habermas' dualistiske socialteori med hans rekonstruktion af den demokratiske retsstats normative grundlag, så får man en kompleks model af forudsætningerne for demokratisk selvbestemmelse i et moderne kapitalistisk samfund. Vigtigt er her at påpege, at Habermas begrebsliggør den konkrete institutionalisering af det demokratiske princip i en kobling mellem den demokratiske viljedannelse, der foregår $\mathrm{i}$ den offentlige sfære, og de love, der vedtages i et folkevalgt parlament, som til gengæld kontrollerer og legitimerer magten i det administrative subsystem og (på keynesiansk vis) fastsætter rammerne for det økonomiske subsystem. Hermed bliver det også tydeligt, hvorfor globaliseringen volder Habermas så mange bekymringer. Ifølge Habermas er det en nødvendig forudsætning for demokratisk selvbestemmelse, at den demokratiske viljedannelse og lovgivning kanaliseres gennem lovens 'sprog' ud i en effektiv politisk styring af de funktionelle subsystemer. Men den grundlæggende udfordring, som globaliseringen konfronterer den demokratiske retsstat med, er jo lige præcis, at det økonomiske subsystem er brudt fri af den nationalstatslige regulerings spændetrøje og har reorganiseret sig på et globalt niveau - hvorved 'politikken' (demokratiet) har mistet kontrollen med 'markedet' (kapitalismen). 
Da det globale økonomiske system stadig står overfor politisk fragmenterede nationalstater, der hverken har kapacitet eller rækkevidde til at kontrollere globalt mobile pengestrømme, så har det økonomiske system opnået en enorm 'strukturel magt' over den demokratiske politik. Dette giver sig blandt andet udslag i, hvad Habermas kalder systemimperativernes kolonisering af livsverdenen. Denne tese - der er en genformulering af Georg Lukács' begreb 'tingsliggørelse' - refererer til en bestemt form for social patologi, hvor den strategiske handlen trænger ind i livsverdenen og erstatter den kommunikative handlen som medium for handlingskoordinering. Koloniseringstesen er en tese om, at den økonomiske rationalitet under visse betingelser kan fortrcenge de kulturelle ressourcer i livsverdenen, der gør os i stand til at orientere os moralske og etisk. Ifølge Habermas opstår de betingelser præcis, når 'politikken' mister styringskapaciteten over 'markedet', hvilket blotlægger vejen for, at økonomisk-rationelle imperativer kan migrere direkte ind i livsverdenens komponenter (kultur, normer, og personlighedsstrukturer). Habermas forklarer dermed den neoliberale markedsideologi som en konsekvens af - snarere end årsag til - markedernes frisættelse og globaliseringen af det økonomiske subsystem (Habermas 1981b, 489-548). ${ }^{16}$

Den teoretiske og analytiske motivation bag Habermas’ insisteren på, at den demokratiske selvbestemmelse må reorganiseres på europæisk plan, bør hermed også være klar. Det er præcis fordi, han er overbevist om, at nationalstaten ikke længere har den fornødne styringskapacitet og rækkevidde til at kontrollere det globaliserede økonomiske subsystem, at Habermas er så varm en fortaler for en gentækning af EU som et supranationalt demokrati. For kantianeren Habermas er dette langt fra et trivielt forhold. Det er grundlæggende et spørgsmål om, at mennesker, der ikke råder over de institutionelle ressourcer til på demokratisk vis at kunne bestemme over deres sociale omverden, er underlagt en særlig form for heteronomi: Deres skæbne bestemmes af uregulerede sociale strukturer snarere end deres egne kollektive fornuftsbeslutninger, og samtidig koloniseres deres politiske bevidsthed af systemimperativer, der undergraver deres evne til at forholde sig oplyst og kritisk til sig selv og deres sociale omverden.

Habermas er som sagt enig med Streeck i, at EU's nuværende form kun føjer spot til skade. Efter krisen i 2008 har EU ifølge Habermas udviklet sig mere og mere i retning af en postdemokratischen Exekutivföderalismus - altså en teknokratisk og tenderende-

\footnotetext{
${ }^{16}$ Koblingen mellem globalisering og kolonisering er bekræftet i personlig samtale med Habermas.
} 
despotisk magtstruktur med beslutningsmagten i stadigt højere grad samlet hos regeringscheferne i det mellemstatslige Europæiske Råd, hvor topmødebaserede kompromisbeslutninger bliver forhandlet på plads bag lukkede døre, snarere end hos det supranationale Europæiske Parlament (Habermas 2011). Ligesom Streeck er Habermas også overbevist om, at EU har tjent neoliberalismens og markedernes sag snarere end demokratiets; Habermas’ ønske om en demokratisering af EU kan altså forstås både som en hensigt om at høste EU's institutionelle potentiale for demokratisk regulering af og kontrol med de globale markeder, samt som en hensigt om offensivt (snarere end defensivt) at imødegå en - demokratisk set - destruktiv kraft i det europæiske politiske liv.

I sine seneste skrifter har Habermas udviklet en normativ model for EU som et supranationalt demokrati, der begrebsligt bygger på en nyfortolkning af Unionens eksisterende struktur som placeret imellem et mellemstatsligt samarbejde og en overnational føderal enhedssuveræn. Først og fremmest insisterer Habermas dog på, at den teknokratiske udviklingsretning må brydes: Rådet må indkalde til et forfatningskonvent, der skal give det europæiske projekt en ny, demokratisk begyndelse - uanset de oplagte risici herved. Habermas er imidlertid overbevist om, at den eksisterende institutionelle struktur i EU faktisk er både parat og velegnet til en mere gennemgribende demokratisering. Han peger især på to institutionelle innovationer, som har kendetegnet det europæiske projekt. For det første er det et særkende ved EU, at den supranationale ret (udlagt af EU-domstolen) har forrang over den nationale lovgivning, mens nationalstaterne har forbeholdt sig voldsmonopolet og råder over langt mere omfattende administrative ressourcer end Bruxelles (Habermas 2011, 20). For det andet argumenterer Habermas for, at udviklingen af EU har fulgt det implicitte (og endnu ikke fuldt udfoldede) princip, at suveræniteten i Unionen er delt mellem unionsborgere og nationalstaternes respektive demoi. Dermed er hver borger både unionsborger og borger i sin nationalstat, og repræsenteres i sin første kapacitet i Det Europæiske Parlament og i sin anden kapacitet gennem regeringslederne i Det Europæiske Råd. Dermed bliver nationalstaten ikke opslugt i en centraliseret enhedsføderation i Habermas' normative model for EU som supranationalt demokrati, men forbliver tværtimod "guarantors of law and freedom" (Habermas 2011, 41). Det sidste, men vigtige element i Habermas' model er en reform af de europæiske institutioners indbyrdes forhold og relative vægt, således at Rådet bringes sammen med et styrket Parlament $\mathrm{i}$ form af et over- og underkammer (ikke ulig den tyske 
model), mens Kommissionen, hvis sammensætning afhænger af det politiske flertal i Parlamentet, står til ansvar over for begge kamre.

Vi har hermed nået det punkt, hvor vi kan tage bestik af Streeks svar på Habermas’ kritik. Den lettere defensive tone, der kendetegner dette svar, bærer præg af en tydelig utilfredshed med at blive skudt 'nostalgi' og sværmeri for Kleinstaaterei i skoene af Habermas (der underviste den unge Streeck ved Goethe Universitetet i Frankfurt), men Streecks strategi er umiskendeligt offensiv: Han zoomer ind på Habermas' forsvar for ØMU'en som det svageste led i hans argumentation, dissekerer de politisk-økonomiske forudsætninger for en levedygtig politisk union, og giver derved tungtvejende grunde til at konkludere, at "European integration [...] has become a modernization project that has ceased to be modern, and whose last chance to become democratic has long been missed.“(Streeck 2014a, 218)

III

Streeck og Habermas er enige om, at ØMU'en i dens nuværende form lider under en række fundamentale konstruktionsfejl, der bl.a. indebærer, at Eurolandene kun kan overkomme indbyrdes forskelle i konkurrenceevnen - som euroen i sig selv bidrager til at forværre, da dens værdi f.eks. er lavere end en hypotetisk tysk mark og højere end en italiensk lire - gennem kontraproduktive neoliberale 'strukturreformer' i de lavproduktive lande. I lighed med bl.a. den franske økonom Thomas Piketty insisterer Habermas på, at disse konstruktionsfejl kan overvindes "only if cross-border transfer payments with the corresponding transnational redistribution effects were accepted in the monetary union” (Habermas 2015, 9; Piketty 2015). Når Habermas plæderer for større europæisk solidaritet, så er det i høj grad begrundet i en præmis om, at solidaritet er en nødvendig forudsætning for den transnationale omfordeling fra de velhavende nordlige medlemsstater til de mindre velhavende sydlige og østlige medlemsstater, som igen er en nødvendig forudsætning for at undslippe euroens nuværende neoliberale implikationer (Habermas 2015).

Første skridt i Streecks modargumentation er at demonstrere, hvor ekstremt krævende denne nødvendige forudsætning reelt er - selv hvis vi forestiller os (hvilket Streeck også har svært ved), at Habermas’ normative model for EU som et supranationalt demokrati kan realiseres. Streeck sammenligner med de regionale transferbetalinger, som 
Italien og Tyskland har gennemført for at udvikle og modernisere henholdsvis de sydlige italienske regioner og det gamle Østtyskland, og han vurderer, at et effektivt niveau af europæiske transferbetalinger (der for nuværende kun udgør ca. 0,3\% af EU's BNP) ville kræve en forhøjelse af EU's budget fra 1\% til 4\% af EU's samlede BNP. Selvom dette måske ikke lyder af meget, så skal det ses i lyset af, at det reelt primært er Tyskland, Frankrig og Holland, der i dag finansierer de regionale udviklingsmidler i EU. For Tyskland ville det f.eks. kræve, at det føderale budget skulle forhøjes med 15\%, der altså skulle gå ubeskåret til transnational omfordeling. Streeck påpeger ganske overbevisende, at de dertil nødvendige skatte- og afgiftsforhøjelser næppe ville finde meget opbakning hos de tyske vælgere (Streeck et al 2014).

Det andet skridt i Streecks argumentation er at pege på, at Eurozonen er præget af en væsentlig højere grad af kulturel og politisk-økonomisk heterogenitet end sammenlignelige valutaunioner, inklusiv USA. Dette indebærer ikke kun, at den europæiske solidaritet, som Habermas efterspørger og opfatter som en nødvendig forudsætning i sin normative model, ifølge Streeck med garanti vil lade vente på sig. Det indebærer også, at 'indenrigspolitikken' i Eurozonen sandsynligvis vil tage form af stigende international konflikt mellem nordlige donorlande, der vil søge at begrænse og kræve supranational detailkontrol med de omfordelte midler, og de sydlige og østlige modtagerlande, der vil opfatte kontrollen som euro-imperialisme og føle sig ydmyget af og lide under at blive underlagt eksternt styre med krav om fortsatte strukturreformer, hvilket kan medføre højrepopulistiske reaktioner. For Streeck er valutaunionen altså ikke en samlende kraft i den europæiske integration; tværtimod er han overbevist om, at euroen snarere er "the culmination of the European variant of the neoliberal immunization of expanding capitalist markets against egalitarian-interventionist democratic politics, as has become the dominant trend worldwide since the postwar order of democratic capitalism has come to an end." (Streeck 2014b, 216)

Efter min opfattelse kulminerer debatten mellem Habermas og Streeck i et uløst dilemma. Dette dilemma er resultatet af, at begge identificerer afgørende problemer i den andens argumentation: Mens Streeck med rette påpeger, hvor urealistisk en opfyldelse af de nødvendige forudsætninger for en europæisk transferunion er, så påpeger Habermas med rette, at Streecks tilbagetrækning til nationalstaten som et last line of defence mod afdemokratiseringen af den europæiske kapitalisme, ikke vil kunne løse de 
massive strukturelle problemer, som den økonomiske globalisering har skabt for de kapitalistiske demokratier. Sagt med andre ord, så er Habermas' normative model den eneste måde, hvorved de globale markeder igen kan blive underlagt demokratisk overhøjhed, men det er næsten umuligt at forestille sig, at det for nuværende kan realiseres $\mathrm{i}$ praksis. Streeck er da også fuldt ud bevidst om, at han hans 'svar' på de udfordringer, han identificerer, er langt fra tilfredsstillende. Som han anfører i de næsten defaitistiske, afsluttende bemærkninger i Gekaufte Zeit:

If, for the foreseeable future, the historically developed differences among European nations are too great to be integrated into a common democracy, then the institutions representing those differences may possibly, as a second-best solution, be used as a stumbling block on the downhill slope into a single market state purged of democracy. (Streeck 2014a, 336)

Dette står i stærk kontrast til Streecks anerkendelse af, at demokratiets genfødsel vil kræve omfattende reformer af den europæiske og internationale politiske økonomi: "Today, a solution to the ongoing financial and fiscal crisis seems to require nothing less than a redefinition of the relationship between the polity and the economy involving a deep restructuring of the international state system, especially in Europe, the heartland of the modern welfare state." (Streeck 2014a, 91) Han taler blandt andet om nødvendigheden af at udvikle et system med omfattende og vidtrækkende reformer, om hvordan "globalization might be retailored or even - horribile dictum - scaled back to become compatible with egalitarian democracy" (Streeck 2014b, 218):

[This] would include the successor to the dollar as a reserve currency, the empowerment of states and international organizations to set limits to the free movement of capital, regulation of the havoc caused by the shadow banks and the global creation of money and credit, as well as the introduction of fixed but adjustable exchange rates. (Streeck 2015, 25).

Det er dog nærmest umuligt at forestille sig, hvordan frivillige aftaler mellem nationalstater skal kunne realisere så omfattende forandringer i den globale økonomi uden sup- 
ranationale institutioner med magt til at løse de kollektive handlingsproblemer, som nødvendigvis vil opstå. Her er det svært ikke at erklære sig enig med Habermas:

\begin{abstract}
Evidently, the political decision-making power of nation-states that jealously guard their long-since hollowed-out sovereignty is not sufficient to escape the grip of the imperatives of a colossally bloated and dysfunctional banking sector. States that do not unite to form supranational units, and have to rely on international treaties alone, fail when faced with the political challenge of reconnecting the banking sector with the needs of the real economy and reducing it to the functionally required scale. The states in the European Monetary Union are confronted in a special way with the task of bringing irreversibly globalized markets within the ambit of indirect but wellaimed political influence. [...] Without the pressure exerted by the will-formation of a vital civil society that can be mobilized across national borders, a self-propelling Brussels executive lacks the strength and the motivation to re-regulate untamed markets in socially sustainable ways. (Habermas 2015, 90)
\end{abstract}

Her lurer en særdeles ubekvem konklusion. Habermas har givetvis ret i, at nationalstaterne uigenkaldeligt har mistet styringskompetencen over globale markeder, og at EU bør gentænkes som supranationalt demokrati, hvis den demokratiske selvbestemmelse skal have nogen fremtid på europæisk jord. Men Streeck har gode grunde til at mane til besindighed: Det EU, vi under alle realistiske forudsætninger faktisk lever i og kommer til at leve med, bliver nok snarere en international konsolideringsstat, der i stigende grad vil facilitere en fortsat afdemokratisering af den europæiske kapitalisme, en kolonisering af vores politiske bevidsthed og skabe grobund for fornyet international konflikt på det europæiske kontinent.

Det eneste håb, der byder denne dystre forudsigelse trods, er måske de sydeuropæiske folkelige protestbevægelser og partier (Syriza, Podemos, etc.) samt gryende paneuropæiske demokratibevægelser (DiEM25), der stædigt fastholder en modstand mod den neoliberale sparekurs, men samtidig søger en europæisk løsning på EU’s problemer. DiEM25, en bevægelse grundlagt af den tidligere græske finansminister Yanis Varoufakis, deler f.eks. Habermas' krav om et europæisk forfatningskonvent som en del af et mere overordnet mål om at demokratisere EU. Det store spørgsmål er dog dels, om denne demokratisering fra neden kan vokse sig tilstrækkelig potent til at kunne gen- 
nemtvinge de nødvendige institutionelle reformer af EU, og dels, om den vil kunne danne grundlag for en mere inklusiv europæisk bevægelse, der kan bygge bro mellem Syd- og Nordeuropa, give næring til paneuropæisk solidaritet, og dermed forebygge de fordelingskonflikter på tværs af kontinentet, som Streeck forudsiger.

Dette afhænger givetvis også af, hvordan eliterne og befolkningerne i medlemslandene reagerer på en række andre aktuelle kriser og udfordringer. Flygtningekrisen, der i brede kredse betragtes som en eksistentiel trussel mod det europæiske projekt, kan måske på længere sigt virke som katalysator for en europæisk offentlighed og en tættere solidaritet mellem medlemslandene, der både i henhold til deres økonomiske suverænitet og flygtningekrisen står over for et valg mellem at løse deres problemer sammen eller de facto miste den folkelige selvbestemmelse i ukoordineret anarki. Selvom skyerne for nuværende ser ud til at trække sig sammen over demokratiet i Europa, så er der måske grundlag for et håb om, at et supranationalt demokrati som en fugl Fønix kan genfødes fra asken af et EU i kaos og opløsning, kombineret med en stadigt mere inklusiv europæisk folkelig mobilisering fra neden. Dette håb på demokratiets vegne er givetvis naivt - men læren fra debatten mellem Streeck og Habermas er, at det måske er det eneste håb, vi har.

\section{Litteratur}

Blyth, Mark 2013, Austerity. The History of a Dangerous Idea, Oxford University Press, Oxford.

Dobbs, Richard, Susan Lund, Jonathan Woetzel, og Mina Mutafchieva 2015, "Debt and (not much) deleveraging", McKinsey Global Institute.

Habermas, Jürgen 2015, "Democracy or Capitalism? On the Abject Spectacle of a Capitalistic World Society Fragmented along National Lines", i The Lure of Technocracy, oversat af Ciaran Cronin, Polity Press, Cambridge.

Habermas, Jürgen 2013, ’Demokratie oder Kapitalismus? Vom Elend der nationalstaatlichen Fragmentierung in einer kapitalistisch integrierten Weltgesellschaft", i Demokratie oder Kapitalismus? Europa in der Krise, Blätter Verlagsgesellschaft, Berlin, 75-86.

Habermas, Jürgen 1996, Between Facts and Norms. Contributions to a Discourse Theory of Law and Democracy, oversat af William Rehg, Polity Press, Cambridge.

Habermas, Jürgen 2011, Zur Verfassung Europas. Ein Essay, Suhrkamp Verlag, Berlin. Habermas, Jürgen 1981b, Theorie des kommunikativen Handels. Band 2: Zur Kritik der funktionalistischen Vernunft, Suhrkamp Verlag, Frankfurt. 
Habermas, Jürgen 1981a, Theorie des kommunikativen Handels. Band I: Handlungsrationalität und gesellschaftliche Ratinoalisierung, Suhrkamp Verlag, Frankfurt.

Habermas, Jürgen 1973, Legitimationsprobleme im Spätkapitalismus, Suhrkamp Verlag, Frankfurt.

Mishel, Lawrence og Heidi Schieroltz 2011, "The Sad but True Story of Wages in America," Economic Policy Institute, Washington DC.

Offe, Claus 2006 (1972), Strukturprobleme des kapitalistischen Staates: Aufsätze zur Politischen Soziologie. Veränderte Neuausgabe, udg. af Jens Borchert og Stephan Lessenich, Campus Verlag, Frankfurt.

Piketty, Thomas 2015, Die Schlacht um den Euro: Interventionen, oversat af Stefan Lorenzer, C.H. Beck Verlag, München.

Streeck, Wolfgang og Lea Elsässer 2014, "Monetary Disunion. The Domestic Politics of Euroland", MPIfG Discussion Paper, Vol. 14, No. 17, Max-Planck-Institut für Gesellschaftsforschung, Köln.

Streeck, Wolfgang 2015, "Why the Euro divides Europe", New Left Review, Vol. 95, sept.-okt.

Streeck, Wolfgang 2014b, "Small-State Nostalgia? The Currency Union, Germany, and Europe: A Reply to Jürgen Habermas", Constellations Vol. 21, No. 2, 2014, 213221.

Streeck, Wolfgang 2014a, Buying Time. The Delayed Crisis of Democratic Capitalism, oversat af Patrick Camiller, Verso Books, London (sidehenvisninger referer til ebogsformatet, der afviger fra bogudgivelsen).

Streeck, Wolfgang 2013, Gekaufte Zeit. Die Vertagte Krise des demokratischen Kapitalismus Suhrkamp Verlag, Berlin. 